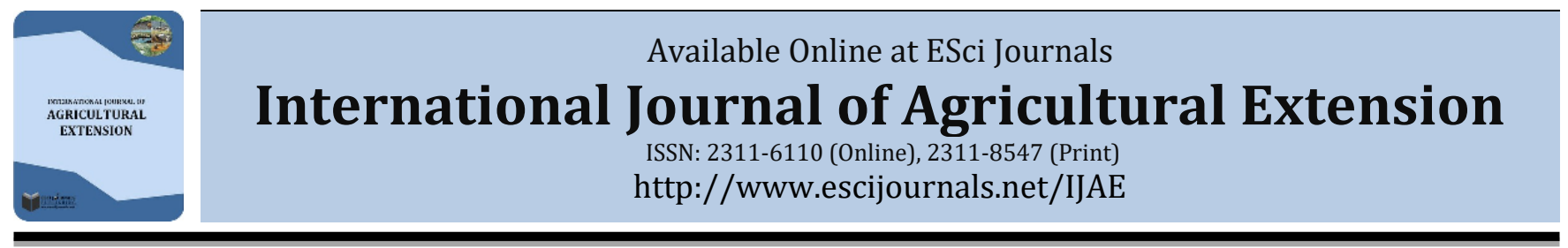

\title{
INDIGENOUS CHICKEN PRODUCTION ENVIRONMENTS, REPRODUCTIVE AND PRODUCTIVE PERFORMANCES AND CONSTRAINTS IN KAFFA ZONE, SOUTH WESTERN ETHIOPIA
}

\author{
aAbiyu Tadele*, bAberra Melesse, bMestawet Taye \\ ${ }^{a}$ Department of Animal Science, Bonga University, Ethiopia. \\ ${ }^{b}$ School of Animal and Range Sciences, Hawassa University, Ethiopia.
}

\section{A B S T R A C T}

The main objective of this study was to describe the production systems, productive performances and associated constraints of indigenous chicken populations in Kaffa Zone. From ten districts of Kaffa Zone, three districts were purposively selected based on their potential for indigenous chicken population and accessibility. From each rural kebeles those households who possess a minimum of five mature indigenous chicken were purposively selected. Then, data on both qualitative and quantitative variables were collected from 300 purposively selected households using a semi-structured questioner. The results indicated that majority of the respondent were female $(71.1 \%)$ and $56 \%$ of them were illiterate. The average family size per household was 5.86. Farmers mainly keep their chickens in the kitchen $(60.7 \%)$ and main houses (30.7\%). Maize (55.7\%) and sorghum (20.3\%) were the major feed supplements provided by the households. The average chicken flock size, age at first egg (months), average egg/hen/clutch (clutch size), clutch number and annual egg/hen/year were 8.68, 6.09, 12.3, 3.6 and 44, respectively. The average hatchability was $80.5 \%$. The major production constraints were predators $(72.7 \%)$ and diseases $(27.3 \%)$ across the studied districts. The type of predators which are commonly occurring included Buteo jamaicensis locally known as "Gace", Helogale hirtula locally known as "Shiifoo" or "Wociwoco", Felis silvestris locally known as "Haallaro" and Felis catus locally known as "Kubbi Kullaro" accounted about 54.6, 24.4, 15.5, and $5.5 \%$ respectively. The effective population size and rate of inbreeding were 486 and $0.111 \%$ indicating chicken populations in the study area are not exposed to inbreeding. In conclusion, the current study indicates illiterate female farmers were mainly involved in care and managing of chickens under scavenging system. The performances of chickens were comparable with the national reports under scavenging system; however, these performances were influenced by predators and diseases. Therefore, educating and training women's should be implemented to improve the overall socio-economic status of the family and benefit them. In addition, successful intervention strategy should be carried out to effectively utilize the existing potentials of indigenous chicken populations in line with predator and disease control programs. Again, conservation of the indigenous chicken populations should also be considered before they have been diluted with exotic breeds.

Keywords: Effective population size, Household Characteristics, Indigenous chicken, Productive performance, Rate of inbreeding.

\section{INTRODUCTION}

In Ethiopia, most of the rural communities keep indigenous chicken populations under scavenging management system (Tadele et al., 2018). Due to the presence of various agro-climatic conditions which enables the rural societies to keep a wide variety of indigenous chicken populations under scavenging

* Corresponding Author:

Email: abiyu.tadele@yahoo.com

(C) 2019 ESci Journals Publishing. All rights reserved. management systems (Azage et al., 2010; Tadele et al., 2018). In Ethiopia chickens are the most widespread and almost every rural family owns chickens, which provide a valuable source of family protein and income (Tadelle et al., 2003). The total chicken population in the country is estimated to be 56.53 million and of these $94.3 \%$ indigenous which are mainly kept by smallholder farmers in scavenging environments (CSA, 2017). The most dominant chicken types reared in Ethiopia are local ecotypes, which show a large variation in body 
conformation, plumage colour, comb type and productivity (Halima et al., 2007; Tadele et al., 2018). However; the economic contribution of the sector is not still proportional to the huge chicken numbers, attributed to the presence of many productions, reproduction and infrastructural constraints (Aberra, 2000). In the rural areas of Ethiopia indigenous chickens has been mainly kept by the poor people due to their significance for the source of animal protein, generation of extra cash incomes and religious /cultural (Alders et al., 2009).

Moreover, the indigenous chicken's populations which have been kept by the majority of rural farmers in Ethiopia are good scavengers and foragers, well adapted to harsh environmental conditions and their minimal space requirements make chicken rearing a suitable activity and an alternative income source for the rural farmers. In addition, the local chicken sector constitutes a significant contribution to human livelihood and contributes significantly to the food security of poor households. Horst (1988) considered the indigenous fowl populations as gene reservoirs, particularly for those genes naked neck $(\mathrm{Na})$ that have adaptive values in tropical conditions. Despite the important roles of local chickens, rearing them can be considered as a sideline agricultural activity. However, the indigenous chicken populations in Ethiopia were neglected for conservation, rather they have been diluting with the imported exotic breeds (Halima et al., 2007).

The indigenous chicken populations which are found in large proportions are often low in their egg production, late in maturation, long broodiness and unimproved (Fisseha et al., 2010; Aberra, 2000). Due to their low genetic potential, the incidence of diseases and predators, limited supplementary feed resources, constraints related to institutional, socio-economic and infrastructural as well as poor management practices contributed for the low production and productivity of chickens. Therefore, the present study was conducted to describe the existing production systems, productive performances and associated constraints of indigenous chicken populations reared in three districts of Kaffa Zone.

\section{MATERIALS AND METHODS}

Description of the study area: This study was conducted in Kaffa Zone which is located between 6o24' to $8013^{\prime}$ North latitude and 35030 ' to 36046' East longitude in South Western part of South, Nation,
Nationalities and Peoples Region. The Zone has a total area of $10,602.7 \mathrm{~km} 2$ which accounts for $7.06 \%$ of the total area of the region. Administratively, Kaffa Zone is divided into ten districts and has three conventional climatic zones based on variations in altitude and temperature. These are highland (2500 - $3000 \mathrm{~m}$ a.s.l), Midland (1500 - $2500 \mathrm{~m}$ a.s.l) and lowland (500 - 1500 $m$ a.s.l) (KZBoFED, 2014). Out of the total area of the Zone, Highland, Midland and lowland cover $11.6 \%$, $59.5 \%$ and $28.9 \%$. The mean annual temperature of the area ranges $10.10 \mathrm{C}-27.50 \mathrm{C}$. The warmest months are February, March and April while the coldest months are July and August. According to the meteorological data obtained from the Zone, the annual rainfall ranges from 1001-2200mm (KZBoFED, 2014). Kaffa Zone is a part of the South West Ethiopian regions which receive the highest amount of rainfall. This is attributable to the presence of the evergreen forest cover on top of the windward location to the moist monsoon winds.

\section{Sampling technique and methods of data collection:}

The study districts were purposively selected based on their potential for chicken population, accessibility and presence of indigenous chicken production. Before the main survey was commenced, a preliminary assessment was made to identify whether there are pure exotic and/or their crosses in the study areas. From ten districts of Kaffa Zone, three districts namely Decha, Chena and Gimbo districts were selected from which 15 rural kebeles (seven from Decha; four from each Chena and Gimbo district) were randomly sampled. Then, a total of 300 households, 20 households from each rural kebeles, that possess a minimum of 5 matured indigenous chickens were randomly selected. Closely adjacent households were also skipped to avoid the risk of sampling chickens sharing the same cock.

Effective population size: Data on effective population size was collected from the surveyed chicken populations which were mature male and female. However, pullets and cockerels which are not ready for breeding were excluded from both districts to estimate the effective population size.

Effective population size for a randomly mated population was calculated following the equation given by Falconer and Mackay (1996).

$N e=\frac{4(N m \times N f)}{N m+N f}$

Where; $\mathrm{Ne}=$ effective population size; $\mathrm{Nm}=$ number of breeding males and $\mathrm{Nf}=$ number of breeding females. 


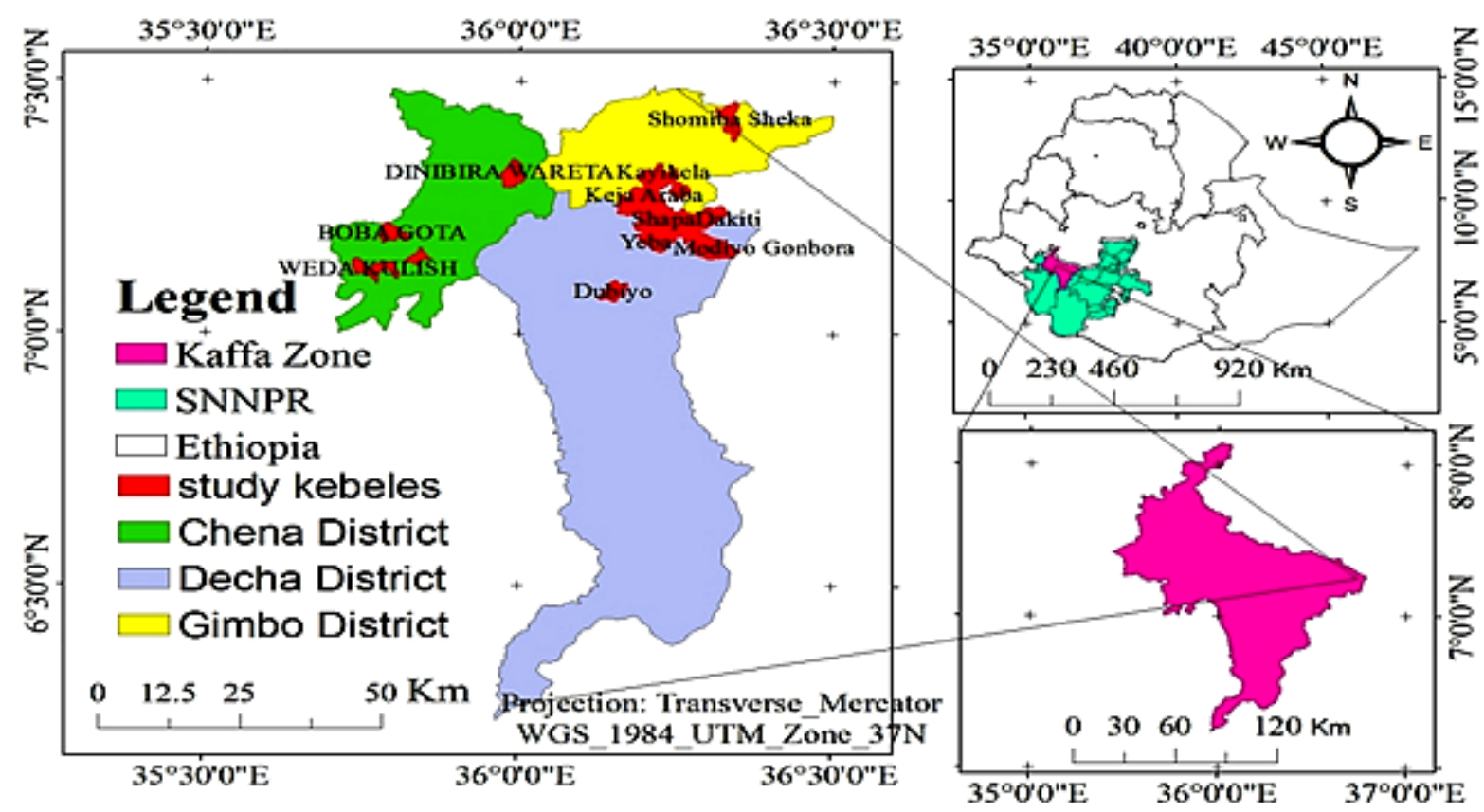

Figure 1. Map of Kaffa Zone displaying study districts and kebeles covered.

Estimation of the rate of inbreeding: Data on the rate of inbreeding was calculated from an effective number of breeding indigenous chickens from the studied districts to determine the current status of inbreeding. Effective population size $(\mathrm{Ne})$ was used to estimate the rate of inbreeding in a population. The rate of inbreeding $(\Delta \mathrm{F})$ for each studied districts and total populations were estimated from the effective population size data following the model adopted from (Falconer \& Mackay, 1996; Maiwashe et al., 2006).

Rate of inbreeding $=\Delta \mathrm{F}=1 /(2 \mathrm{Ne})$

Where;

$\Delta \mathrm{F}=$ rate of inbreeding

$\mathrm{Ne}=$ effective population size

Statistical Analysis: Data collected on socio-economic, production systems, productive performances and constraints of chicken populations were coded and entered into a computer using Microsoft Office Excel 2007. Descriptive statistics were employed to analyze the data in each district and Chi-square $(\chi 2)$ test was also employed to compare the significance of district by using Statistical Analysis System (SAS, 2002, ver. 8.2).

\section{RESULTS}

Household Characteristics of the Study Areas: The household characteristics of the respondents are presented in Table 1. From the total interview indigenous chicken owning farmers, 70.7, 70 and $72.5 \%$ were females in Decha, Chena and Gimbo districts, respectively. A higher proportion of female respondents (71.1\%) than males $(28.9 \%)$ was observed. This indicates that female farmers are mainly involved in managing and caring for chickens in the study districts. The average age of respondents in the present study was 39.9, 41.3 and 39.2 years in Decha, Chena and Gimbo districts, respectively. The educational level of respondents showed that about $66.4,58.7$ and $42.5 \%$ in Decha, Chena and Gimbo districts, respectively were illiterate. This might be due to the fact that farmers in rural communities particularly in this area did not have access to education before. Others can read and write and some were involved in formal education such as primary first cycle (1-4th) ; second cycle (5-8th) and high school (9-10th or 12th) and above in all study districts. The average family size in Decha, Chena and Gimbo districts was 5.97, 5.83 and 5.7 persons, respectively with the overall mean family size of 5.86 persons.

The average chicken flock size per household in Decha, Chena and Gimbo districts was 9.02, 8.83 and 8.01, respectively with the overall mean chicken flock size of 8.68 (Table 2). The largest proportions of chicken populations were reported from Decha and Chena districts and which are significantly higher $(p<0.05)$ than Gimbo district. 
Table 1. Household characteristic of respondents in three districts of Kaffa Zone, South Western Ethiopia.

\begin{tabular}{|c|c|c|c|c|}
\hline \multirow{2}{*}{ Household characteristics } & Decha & Chena & Gimbo & Overall \\
\hline & $\mathrm{N}=140$ & $\mathrm{~N}=80$ & $\mathrm{~N}=80$ & $\mathrm{~N}=300$ \\
\hline \multicolumn{5}{|c|}{ Sex of respondents (\%) } \\
\hline Male & $41(29.3)$ & $24(30)$ & $22(27.5)$ & $87(28.9)$ \\
\hline Female & $99(70.7)$ & $56(70)$ & $58(72.5)$ & $213(71.1)$ \\
\hline Average age of respondents (years) & 39.9 & 41.3 & 39.2 & 40.1 \\
\hline \multicolumn{5}{|c|}{ Educational level (\%) } \\
\hline Illiterate & $93(66.4)$ & $47(58.7)$ & $34(42.5)$ & $174(56)$ \\
\hline Read and write & $10(7.14)$ & $7(8.75)$ & $12(15)$ & $29(10.3)$ \\
\hline Primary first cycle (1-4) & $10(7.14)$ & $10(12.5)$ & $14(17.5)$ & $34(12.4)$ \\
\hline Primary second cycle (5-8) & $19(13.6)$ & $9(11.3)$ & $12(15)$ & $40(13.3)$ \\
\hline High school (9-12 and above) & $8(5.71)$ & $7(8.75)$ & $8(10)$ & $23(8)$ \\
\hline Average family size (number) & 5.97 & 5.83 & 5.7 & 5.86 \\
\hline
\end{tabular}

$N$, Number of observations; Numbers in parenthesis are percentage values.

Table 2. Chicken flock compositions of households in three districts of Kaffa Zone of South Western Ethiopia.

\begin{tabular}{lcccc}
\hline \multirow{2}{*}{ Flock composition } & Decha & Chena & Gimbo & (Mean \pm SE) \\
\cline { 2 - 5 } & $\mathrm{N}=140$ & $\mathrm{~N}=80$ & $\mathrm{~N}=80$ & $\mathrm{~N}=300$ \\
\hline Chicks & $1.3 \pm 0.16$ & $1.40 \pm 0.22$ & $1.05 \pm 0.17$ & $1.26 \pm 0.11$ \\
Pullets & $1.12 \pm 0.08$ & $1.01 \pm 0.12$ & $0.88 \pm 0.12$ & $1.03 \pm 0.06$ \\
Cockerels & $0.54 \pm 0.06^{\mathrm{a}}$ & $0.35 \pm 0.07^{\mathrm{a}}$ & $0.25 \pm 0.06^{\mathrm{b}}$ & $0.4 \pm 0.7$ \\
Hens & $4.36 \pm 0.07$ & $4.33 \pm 0.09$ & $4.20 \pm 0.08$ & $4.3 \pm 0.8$ \\
Cocks & $1.7 \pm 0.05$ & $1.74 \pm 0.07$ & $1.63 \pm 0.06$ & $1.7 \pm 0.03$ \\
Overall & $9.02 \pm 0.24^{\mathrm{a}}$ & $8.83 \pm 0.34^{\mathrm{a}}$ & $8.01 \pm 0.25^{\mathrm{b}}$ & $8.68 \pm 0.28$ \\
\hline
\end{tabular}

$a_{a, b}$ Row means with superscript letters are significantly different ( $\left.P<0.05\right)$; SE, Standard error, $N=$ Number of observations.

Reproductive and Productive Performance of Indigenous Chickens: The performance of indigenous chicken populations is presented in Table 3. Age at first egg (months) was significantly longer for chickens reared in Gimbo (6.3 months) district than Chena (6.1 months) and Decha (6 months) districts. Egg number per hen per clutch in the present study was 12.3, 12.2 and 12.6 eggs in Decha, Chena and Gimbo districts, respectively. An average number of days per clutch (clutch length) was lower in Gimbo district than, Decha and Chena districts, which had similar values. Eggs incubated per hen/clutch in Decha, Chena and Gimbo districts were 10.2, 10.2 and 10 , respectively. The hatchability percentages of chickens reared in Gimbo district was significantly (P < 0.05) lower than Decha chickens and has comparable with Chena district chickens. The district had no significant effect $(\mathrm{P}>0.05)$ on the survivability of chicken. In general, the average egg and clutch number per hen per year in the current study were 44 and 3.6, respectively.

Table 3. Performance of indigenous chickens in three districts of Kaffa Zone of South Western Ethiopia.

\begin{tabular}{lcccc}
\hline \multicolumn{1}{c}{ Parameters } & Decha & Chena & Gimbo & Overall mean \\
\cline { 2 - 4 } \multicolumn{1}{c}{$\mathrm{N}=140$} & $\mathrm{~N}=80$ & $\mathrm{~N}=80$ & $\mathrm{~N}=300$ \\
\hline Age at first egg (months) & $6.0 \pm 0.43^{\mathrm{b}}$ & $6.1 \pm 0.55^{\mathrm{b}}$ & $6.30 \pm 0.69^{\mathrm{a}}$ & $6.1 \pm 0.56$ \\
Egg number per hen/clutch & $12.3 \pm 1.43$ & $12.2 \pm 1.64$ & $12.6 \pm 2.07$ & $12.3 \pm 1.68$ \\
Clutch length/hen(days) & $21.0 \pm 5.1^{\mathrm{a}}$ & $21.0 \pm 5.7^{\mathrm{a}}$ & $19.0 \pm 5.86^{\mathrm{b}}$ & $20.0 \pm 5.3$ \\
Clutch no per hen/year & $3.60 \pm 0.2$ & $3.60 \pm 0.2$ & $3.65 \pm 0.21$ & $3.60 \pm 0.2$ \\
Total egg number per hen/year & $44 \pm 5.3^{\mathrm{ab}}$ & $43.4 \pm 5.7^{\mathrm{b}}$ & $45.6 \pm 7.12^{\mathrm{a}}$ & $44.0 \pm 6.0$ \\
Eggs incubated per hen & $10.2 \pm 0.94$ & $10.2 \pm 0.88$ & $10.0 \pm 1.2$ & $10.2 \pm 1.0$ \\
Number of chicks hatched & $8.34 \pm 1.1$ & $8.21 \pm 0.94$ & $8.0 \pm 1.44$ & $8.20 \pm 1.2$ \\
Hatchability (\%) & $81.6 \pm 7.0^{\mathrm{a}}$ & $80.3 \pm 5.5^{\mathrm{b}}$ & $78.6 \pm 8.9^{\mathrm{b}}$ & $80.5 \pm 7.3$ \\
Number of chicks survived & $4.10 \pm 0.71$ & $4.01 \pm 0.88$ & $3.90 \pm 0.97$ & $4.00 \pm 0.8$ \\
Survivability (\%) & $49.1 \pm 8.7$ & $48.8 \pm 10.0$ & $49.8 \pm 10.3$ & $49.2 \pm 9.5$ \\
\hline
\end{tabular}

$\overline{a, b}$ Row means with superscript letters are significantly different $(P<0.05) ; S D=$ Standard deviation; 


\section{Husbandry Practices of Chickens}

Management Systems: Chicken management systems practised in the three districts is presented in Table 4. This study has revealed that scavenging/free-ranging as the main production systems practised in study districts.

Housing System: Housing system had significantly differed ( $\mathrm{p}<0.05)$ among the studied districts. As presented in Table 4, about $60.7 \%$ of households keep their chicken in the kitchen while $30.7 \%$ of them shared their main houses with their chicken and other farm animals.

Feed and Feeding Practices: In the current study, supplementary feeding for chickens was provided in all study districts. In Gimbo, all the interviewed households provide supplementary feeds to their chickens, whereas 98.6 and $97.5 \%$ in Decha and Chena districts respectively provide supplementary feeds. The common feed supplements feed in the study districts was Maize (55.7\%), Sorghum (20.3\%), and Wheat (10.3\%). Majority (39.7 \%) provide feed twice per day across the study districts.

Watering practices: With regard to the provision of water in the current study, all respondents in Gimbo district provide water while 98.6 and $97.5 \%$ of them in Decha and Chena districts, respectively provide water for their chickens. In the study districts, river water was the major source of water (69.3\%) followed by Borehole water $(22.3 \%)$.

Table 4. Chicken husbandry practices in three districts of Kaffa Zone, South Western Ethiopia.

\begin{tabular}{|c|c|c|c|c|c|}
\hline \multirow[t]{2}{*}{ Parameters } & Decha & Chena & Gimbo & Overall (\%) & Chi' ${ }^{2}$ - test \\
\hline & $\mathrm{N}=140$ & $\mathrm{~N}=80$ & $\mathrm{~N}=80$ & $\mathrm{~N}=300$ & \\
\hline \multicolumn{6}{|c|}{ Management system } \\
\hline Scavenging/free-ranging & $140(100)$ & $80(100)$ & $80(100)$ & $300(100)$ & ns \\
\hline \multicolumn{6}{|c|}{ Housing system } \\
\hline In the kitchen & $91(65)$ & $38(47.5)$ & $53(66.3)$ & $182(60.7)$ & \\
\hline Main houses & $41(29.3)$ & $32(40)$ & $19(23.7)$ & $92(30.7)$ & $9.7^{*}$ \\
\hline Mud houses & $8(5.71)$ & $10(12.5)$ & $8(10)$ & $26(8.67)$ & \\
\hline \multicolumn{6}{|c|}{ Supplementary feeding } \\
\hline Yes & $138(98.6)$ & 78 (97.5) & $80(100)$ & 296 (98.7) & $1.9 \mathrm{~ns}$ \\
\hline No & $2(1.43)$ & $2(2.50)$ & NR & $4(1.33)$ & \\
\hline \multicolumn{6}{|c|}{ Frequency of feeding } \\
\hline Once a day & $18(12.8)$ & $16(20)$ & $32(40)$ & $66(22)$ & \\
\hline Twice a day & $49(35)$ & $34(42.5)$ & $36(45)$ & $119(39.7)$ & $38.3^{* *}$ \\
\hline Three or more time a day & $71(50.7)$ & $28(35)$ & $12(15)$ & $111(37)$ & \\
\hline None & $2(1.43)$ & $2(2.50)$ & NR & $4(1.33)$ & \\
\hline \multicolumn{6}{|c|}{ Feed supplements (\%) } \\
\hline Maize & $74(52.8)$ & $37(46.3)$ & $56(70)$ & $167(55.7)$ & \\
\hline Sorghum & $27(19.3)$ & $28(35)$ & $6(7.50)$ & $61(20.3)$ & \\
\hline Wheat & $13(9.29)$ & $4(5)$ & $14(17.5)$ & $31(10.3)$ & $35.8^{* *}$ \\
\hline Barley & $21(15)$ & $7(8.75)$ & $2(2.50)$ & $30(10)$ & \\
\hline Teff & $3(2.14)$ & $2(2.50)$ & $2(2.50)$ & $7(2.33)$ & \\
\hline No feed & $2(1.43)$ & $2(2.50)$ & NR & $4(1.33)$ & \\
\hline \multicolumn{6}{|c|}{ Watering Practices (\%) } \\
\hline Yes & $138(98.6)$ & $78(97.5)$ & $80(100)$ & $296(98.7)$ & $1.9 \mathrm{~ns}$ \\
\hline No & $2(1.43)$ & $2(2.50)$ & NR & $4(1.33)$ & \\
\hline \multicolumn{6}{|c|}{ Source of water (\%) } \\
\hline $\begin{array}{l}\text { Bore hole } \\
\text { Well } \\
\text { River }\end{array}$ & $\begin{array}{c}10(7.14) \\
7(5.00) \\
121(86.4)\end{array}$ & $\begin{array}{c}15(18.7) \\
12(15) \\
51(63.7)\end{array}$ & $\begin{array}{c}42(52.5) \\
2(2.50) \\
36(45)\end{array}$ & $\begin{array}{c}67(22.3) \\
21(7.33) \\
208(69.3)\end{array}$ & $72.8^{* *}$ \\
\hline No water & $2(1.46)$ & $2(2.50)$ & NR & $4(1.00)$ & \\
\hline
\end{tabular}

$n s=$ non- significant; ${ }^{*} p<0.05 ;{ }^{* *} p<0.01 ; N R$, not Reported; Percentages in parenthesis; $N=$ Number of observations. 
Production Constraints of Indigenous Chicken in the Study Area: Data pertaining to constraints in chicken production is presented in (Table 5). Predators were the most important problem reported to be affecting poultry productivity in all the study districts accounting for 74.3, 80 and $62.5 \%$ in Decha, Chena and Gimbo districts, respectively. The disease was the second constraint as reported by 25.7, 20 and $37.5 \%$ of respondents in Decha, Chena and Gimbo districts, respectively. In all the production constraints reported, significance differences $(\mathrm{P}<0.05)$ were observed among the study districts. The type of predators commonly occurring in the study districts was significantly differed $(\mathrm{P}<0.05)$ across the different sites. These predators, which are mentioned by their scientific and local name included Milvus migrants locally known as "Gace", Helogale hirtula locally known as "Shiifoo" or "Wociwoco", Leptailurvs serval locally known as "Hallaroo" and Felis silvestris locally known as "Kubbi Kullaaro" accounted for about 54.6, 24.4, 15.5, and $5.5 \%$, respectively.

The prevalence of chicken diseases in Decha and Gimbo districts was higher with 98.6 and $97.5 \%$, respectively and in Chena $88.7 \%$ (Table 5). The season had a significant effect $(\mathrm{p}<0.05)$ on the occurrence of disease and the highest outbreak was recorded on the rainy season, as witnessed by 71.8, 53.2 and $52.1 \%$ of respondents in Gimbo, Chena and Decha districts, respectively.

This indicates rainy season was more favourable for the growth of disease causing agents across the study districts. Overall, the chi-square test suggests there were significant differences $(\mathrm{p}<0.01)$ in the prevalence of disease and in a favorable season of disease occurrences $(\mathrm{p}<0.05)$ across the study districts.

Table 5. Major production constraints of chicken in three districts of Kaffa Zone, South Western Ethiopia.

\begin{tabular}{|c|c|c|c|c|c|}
\hline Parameters & Decha & Chena & Gimbo & Overall (\%) & $\mathrm{X} 2$ - test \\
\hline \multicolumn{6}{|c|}{ Production constraints (\%) } \\
\hline Diseases & $36(25.7)$ & $16(20)$ & $30(37.5)$ & $82(27.3)$ & \multirow[t]{2}{*}{$6.5^{*}$} \\
\hline Predators & $104(74.3)$ & $64(80)$ & $50(62.5)$ & $218(72.7)$ & \\
\hline \multicolumn{6}{|c|}{ Types of predators (\%) } \\
\hline Milvus migrants (Gace) & $63(59.6)$ & $32(50)$ & $25(50)$ & $120(54.6)$ & \multirow{4}{*}{$19.2^{*}$} \\
\hline Helogale hirtula (Shiifoo/Wociwocoo) & $27(26)$ & $16(25)$ & $10(20)$ & $53(24.4)$ & \\
\hline Leptailurvs serval (Hallaroo) & $10(10.6)$ & $14(21.8)$ & $9(18)$ & $33(15.5)$ & \\
\hline Felis silvestris (Kubbi Kullaaro) & $4(3.85)$ & $2(3.13)$ & $6(12)$ & $12(5.5)$ & \\
\hline \multicolumn{6}{|c|}{ Prevalence of disease (\%) } \\
\hline$\overline{\text { Yes }}$ & $138(98.6)$ & $71(88.8)$ & $78(97.5)$ & $287(95.7)$ & \multirow[t]{2}{*}{$12.7^{* *}$} \\
\hline No & $2(1.43)$ & $9(11.3)$ & $2(2.50)$ & $13(4.33)$ & \\
\hline \multicolumn{6}{|c|}{ Favourable season (\%) } \\
\hline Rainy & $75(53.6)$ & $51(63.7))$ & $58(72.5)$ & $184(61.3)$ & \multirow[t]{2}{*}{$7.9^{*}$} \\
\hline Dry & $65(46.4)$ & $29(36.3)$ & $22(27.5)$ & 116 (38.7) & \\
\hline
\end{tabular}

$X^{2}$ - test $=$ Chi-square test; ${ }^{* *} p<0.01 ;{ }^{*} p<0.05$;

Numbers in parenthesis are percentage values; Names of predators are in their scientific name, and names in brackets are in Kafigna language, the official working language of Kaffa Zone.

Effective Population Size and Inbreeding: As presented in Table 6 , the overall effective population size $(\mathrm{Ne})$ was found to be 486 while the rate of inbreeding were $0.073,0.126$ and $0.133 \%$ in Decha, Chena and Gimbo districts, respectively with the overall rate of inbreeding $0.111 \%$ across the study areas. In
Decha district the percentage value of the rate of inbreeding was comparatively lower than Chena and Gimbo districts, however, Chena and Gimbo districts had comparable percentage value. The variation of $\mathrm{Ne}$ in the studied district might be due to the small number of cocks kept in the studied households. 
Table 6. Effective population size and inbreeding rate of indigenous chicken populations reared in study area.

\begin{tabular}{lccccccc}
\hline Study districts & $\mathrm{Nm}$ & $\mathrm{Nf}$ & $\mathrm{N}$ & $\mathrm{Nm} / \mathrm{Nf}(\%)$ & $\mathrm{Ne}$ & $\mathrm{Ne} / \mathrm{N}(\%)$ & $\Delta \mathrm{F} \%$ \\
\hline Decha & 238 & 611 & 849 & 39 & 685.1 & 80.7 & 0.073 \\
Chena & 139 & 346 & 485 & 40.2 & 396.7 & 81.8 & 0.126 \\
Gimbo & 130 & 336 & 466 & 38.7 & 375 & 80.5 & 0.133 \\
Overall & 507 & 1293 & 1800 & 39.3 & 486 & 81 & 0.111 \\
\hline
\end{tabular}

Ne, Effective population size; $\Delta F$, Rate of inbreeding; $\mathrm{Nm}=$ Number of breeding male chicken; $\mathrm{N} f=$ Number of breeding female chicken; $N m / N f(\%)=$ Ratio of Male: Female chickens in percent; $N=$ Total breeding chicken populations $(\mathrm{Nm}+\mathrm{Nf}) ; \mathrm{Ne} / \mathrm{N}(\%)=$ Ratio of breeders contributing efficiently genes to the population .

\section{DISCUSSION}

Household Characteristics of the Study Area: In the present study, majority of respondents were females (71.1\% which was in agreement with the results of various scholars in the country (Moreda et al., 2013; Hailemichael, 2015; Wondu et al., 2013). However, the highest value of males (62\%) was reported by Mulgeta and Tebikew (2013). The result on educational level obtained in the current study with higher illiterate (56\%) was also in line with the findings of different scholars (Halima et al., 2007; Moreda et al., 2013; Hailemichael, 2015; Wondu et al., 2013). The average family size in the present study (5.86) was in close agreement with the findings of Halima et al. (2007), Moreda et al. (2013) and Hailemichael (2015). Lower family sizes: 4.5 and 4.06 person per households was reported by Mulgeta \& Tebikew (2013) and Solomon et al. (2013), respectively. From the present findings and the reports from various parts of the country, it is clear that female farmers are the main to care and manage chickens. Hence, it is important to empower women's through better education as they are the most to contribute a significant role in the improvement of indigenous chicken production systems. In line with this Halima et al. (2007) also indicated that educating women will improve the overall socio-economic status of the family and society.

Reproductive \& Productive Performance of Indigenous Chickens: The average age at first egg (6.1) of chickens in the current study was in close agreement with the findings of Deneke et al. (2014) from the Southeastern Oromia Zone. High age values at first egg of indigenous chickens were reported from various parts of the country by Tadele et al. (2003), Aberra et al. (2013), Melkamu et al. (2013) and Nebiyu et al. (2013). Low age at first egg was also reported from Northwest Ethiopia by Addisu et al. (2013) and Solomon et al. (2013) with
5.6 and 5.2 months, respectively. A different report on the age of chickens at first egg might be due to lack of proper supplementary feeds, availability of scavengable feed resources, disease outbreak and provision of clean water by the households. The present finding with regard to average egg production per clutch per hen (12.3), number of eggs incubated (10.2) and number of chicks hatched (8.2) differed from the results of Melkamu \& Andargie (2013), Nebiyu et al. (2013) and Solomon et al. (2013). However, it was in close agreement with the findings of Addisu et al. (2013), Mulgeta \& Tebikew (2013) and also was comparable with the reports of CSA (2017). The highest value of eggs/clutch/hen was reported from Eastern Gojam Zone by Melkamu \& Andarge (2013) 17 eggs/clutch/hen. The average clutch number per hen per year (3.6) and total egg number per hen per year (44) in the current study was comparable with the findings of Addisu et al. (2013) which was 3.62 and 46, respectively. However, high values of clutch number and egg number per hen per year were reported by Melkamu \& Andargie (2013) and Solomon et al. (2013). The management aspects of the households' chicken rearing might be the reason contributing to the observed variations in the production and reproduction traits of indigenous chickens in the country.

The average hatchability ( $80.5 \%$ ) of chickens in the current study was comparable with the results of Aberra et al. (2013) and Deneke et al. (2014) in which the hatchability percentages were 79.1 and 81.5 percents, respectively. However, observations by several scholars in various parts of the country were higher than the present study (Worku et al., 2012; Nebiyu et al., 2013; Solomon et al., 2013). On the other hand, lower hatchability values were reported from various parts of the country (Melkamu \&Andargie, 2013; Getachew et al., 2015). The average survival rate of chickens in the 
present study (49.2\%) was lower than those reported by Aberra et al. (2013), Nebiyu et al. (2013), Deneke et al. (2014) and Getachew et al. (2015) with the respective values of 58.3, 52.3, 62.7 and 66.5 percent. These variations in the hatchability and survivability of chicks might be due to storage condition of the egg, incubation materials, quality of eggs, to some extent the hen factors, seasonal outbreak of disease, predator attacks, poor nutrition and management, availability of scavenging feed resources and feed supplements.

Husbandry Practices of Chickens in the Study Area: In the present study, all the studied districts manage their chickens in the scavenging system. These findings are in close agreement with the observations of different scholars in various parts of the country, where scavenging was the dominant type of chicken rearing (Melkamu \& Andargie, 2013; Nebiyu et al., 2013; Solomon et al., 2013). This management system might be due to the fact that indigenous chickens can best fit as they receive few inputs such as feed supplementation and health care for their survival, production and productivity.

The majority of chickens in the study area are kept in the kitchen (60.7\%) and main houses (30.7\%) during night time which is in agreement with the reports of Halima et al. (2007), Addisu et al. (2013), Moreda et al. (2013) and Mulgeta et al. (2013). A study conducted in western Kenya indicated a similar scenario where the majority of the households (73\%) in the rural areas kept their chickens in the kitchen or in main houses (Justus et al., 2013).

In the study districts chickens were provided with supplemental feeds (98.7\%), which is in line with those reported by Addisu et al. (2013), Melkamu \& Tebikew (2013), Mulgeta et al. (2013) and Solomon et al. (2013).

Water is provided for chicken from different sources such as river (69.3\%), Borehole (22.3\%) and well $(7.33 \%)$ which is also common scenario in various areas (Addisu et al., 2013; Nebiyu et al., 2013; Solomon et al., 2013; Wondu et al., 2013). The present study agrees with the findings of Nebiyu et al. (2013) and Solomon et al. (2013) who noted river water as the major source for chickens. However, the current study disagrees with the reports of Wondu et al. (2013) who found that tap water as the major source (92\%) for chickens reared in Nothern Gonder Zone of Amhara region. Thus, the current study suggests most of the rural society in the studied districts depends mainly on river, borehole or well water due to lack of tap water.

Production Constraints of Chickens in the Study Area: The major constrains of chickens in the study districts were predators (72.7\%) and diseases (27.3\%). This result is in agreement with the reports of Melkamu \& Wube (2013), Alem (2014), Matiwos \& Selamawit (2014) where predators were reported to be the major problems in indigenous chickens reared in various parts of the country. In the current study, the types of diseases affecting chicken production were not included as farmers could not identify clearly the types of diseases affecting their chickens. However, the various types of predators which are reported in their scientific names and local languages such as Milvus migrants locally known as "Gace", Helogale hirtula locally known as "Shiifoo" or "Wociwoco", Leptailurvs serval locally known as "Hallaroo" and Felis silvestris locally known as "Kubbi Kullaaro" accounting 54.6, 24.4, 15.5, and $5.5 \%$, respectively, which are also reported in various parts of the country. As reported by Alem (2014), Hawk, Genet, Wild cat, Fox and snake were found to be the most important predators occurred in the low and mid land agro-ecological zones of central Tigray. Similarly, as reported by Matiwos \& Selamawit (2014), Wild cats, Wild Egyptian vulture, Honey bagger and Snakes were being the most challenging predators in Amaro districts. Hence, the various types of predators observed in the current study and elsewhere might be due to the agroecological suitability of the country for predators.

Effective population size ( $\mathrm{Ne}$ ) and rate of inbreeding $(\Delta \mathbf{F})$ : To obtain some idea on the $\mathrm{Ne}$ and rate of inbreeding over generations, Ne was calculated based on the total chicken flocks of farmers who possessed their own breeding male and female chickens. The $\mathrm{Ne}$ in the current study ranged from 375 to 685 with the average $\mathrm{Ne}$ of 486 implying number of breeding individuals were comparatively low. According to Maiwashe et al. (2006), $\mathrm{Ne}$ is a measure of genetic variability within a population where large values of Ne indicate more variability and small values of $\mathrm{Ne}$ indicate less genetic variability. The low Ne estimated in the current study suggests that the breeding population might be too small. Even if neighbouring flocks were scavenging together, which gives an opportunity for breeding cocks to mating with hens, the number of cocks per flock is still considered lower than required.

Effective breeding population size and the corresponding $\Delta \mathrm{F}$ reported by Nigussie et al. (2010) by 
considering the average mean flock size of chickens for Mandura, Horro and Konso, village chickens, Eskindir et al. (2013) from Jarso districts and Hailemichael (2015) for Endamehari, Ofla and Raya- Azebo districts' chicken population were in agreement with the present study. However, the report of Eskindir et al. (2013) from Horro districts (3.73) was lower than the current study due to the fact that they considered the average flock size rather than taking the total number of chickens in computing both parameters, i.e., $\mathrm{Ne}$ and $\Delta \mathrm{F}$. However, the result reported by Hagan et al. (2013) from Ghana for Coastal, Forest and Guinea Ecological Zones which were $13.3,11.3$ and 12.9 respectively had three-fold higher than those reported in Ethiopia. The current study was also in a similar scenario with the result reported by Rusfidra et al. (2014).

The average rate of inbreeding $(0.111 \%)$ in the current study was in good agreement with the reports of various scholars in the country. Hailemichael (2015) reported $0.16,0.15$ and 0.14 rate of inbreeding for Endamehari, Ofla and Raya-Azebo districts of the chicken population, respectively. The rate of inbreeding reported by Eskindir et al. (2013) falls in the range of 0.13 to 0.12 which is in line with the current study. The rate of inbreeding values reported by Hagan et al. (2013) was comparable with the observed values in Decha chicken populations. According to Henson (1992), the acceptable level of inbreeding rate per generation is between $1 \%$ and $2 \%$. Therefore, the rate of inbreeding obtained from the current study was low which suggests that chicken populations in the study area are not exposed to inbreeding.

\section{CONCLUSION AND RECOMMENDATIONS}

The current study indicated scavenging as the major chicken production systems practised across all the study districts. Due to this reason the average annual egg production as well as total egg production throughout the life of the hens is very low. Indigenous chickens have long age of sexual maturity and long brooding period. The major production constraints were predators and diseases across the studied districts. Effective population size and inbreeding rate obtained in the present study indicates the chicken populations are not exposed for inbreeding. However, the distribution of exotic chicken breed has been increasing from time to time, which might lead for the loss of genetic resources in the future. Therefore, an adequate supplementary fedding, health care and housing should be carried out to improve production performances and protect them from predators and disease. In addition, conservation of indigenous chicken need to be implemented before they have been diluted with exotic breeds.

\section{ACKNOWLEDGEMENTS}

The authors would like to acknowledge the Ministry of Agriculture and Natural resource, Mizan Agricultural, Technical, Vocational and Educational Training College, for their financial support during the research work. We further express our deepest gratitude for Kaffa Zone, Decha, Gimbo and Chena district Livestock and Fishery development offices for their kind support. Finally, we are also indebted to thank those farmers and development agents who participated in this study.

\section{REFERENCES}

Aberra M. (2014). The significance of scavenging chicken production in the rural community of Africa for enhanced food security. World's Poultry Science Journal, 70, 593-606.

Aberra M. (2000). Comparative studies on performance and physiological responses of Ethiopian indigenous ("Angete-melata") chicken and their F1 crosses to long term heat stress. PhD Thesis. Martin-Luther University, Halle-Wittenberg, Berlin. pp. 4-5.

Aberra M., S. Maak, R. Schmidt \& G. von Lengerken, (2011). Effect of long-term heat stress on some performance traits and plasma enzyme activities in Naked-neck chickens and their F1 crosses with commercial layer breeds. Livestock Science, 141, 227-231.

Aberra M., Z. Worku \& Yosef Teklegiorgis. (2013). Assessment of the prevailing handling and quality of eggs from scavenging indigenous chickens reared in different agro-ecological Zones of Ethiopia. Journal of Environmental and Occupational Science, 2(1), 1-8.

Addisu H., H. Mazengia \& ZewduWuletaw. (2013). Indigenous chicken production system and breeding practice in North Wollo, Amhara region, Ethiopia. Scholarly Journal of Agricultural Science, 3(10), 433-444.

Alem T. (2014). Production and Reproduction Performance of Rural Poultry in Lowland and Midland Agro-Ecological Zones of Central Tigray, Northern Ethiopia. British Journal of Poultry Sciences, 3 (1), 06-14.

Azage T., Berhanu Gebremedhin \& D. Hoekstra. (2010). 
Livestock input supply and service provision in Ethiopia. Challenges and opportunities for market oriented development. IPMS (Improving productivity and Market success) of Ethiopian farmer project working paper 20. ILRI (International Research Institute). Nairobi, Kenya. Pp48.

Central Statistical Agency (CSA). (2017). Agricultural Sample Survey Statistical Bulletin Addis Ababa, Ethiopia. pp188.

Falconer, D.S. \& MacKay T.F.C. (1996). Introduction to Quantitative Genetic. Longman, New York.

Fisseha M., A Melesse \& T. Dessie. (2010). Assessment of village chicken production system and evaluation of the productive and reproductive performance of local chicken ecotype in Bure district, North West Ethiopia. African Journal of Agricultural Research, 5 (13), 1739-1748.

Hagan, J. K. M. Bosompem \& I. A. Adjei. (2013). The productive performance of local chickens in three Ecological Zones of Ghana. ARPN Journal of Agricultural and Biological Science, 8(1), 51-56.

Hailemichael N., K. Kebede \& N. Ameha. (2015). Phenotypic and Morphological Characterization of Indigenous Chicken Populations in Southern Zone of Tigray, Ethiopia. Journal of Biology, Agriculture and Healthcare, 5, 21, 132-141.

Halima H., Neser, F.W.C. \& van Marle-Koster, E. (2007). Village based indigenous chicken production system in north-west Ethiopia. Trop. Anim. Health Product. 39, 189-197.

Maiwashe, A., K.A. Nephawe, R.R. van der Westhuizen, B.E. Mostert \& H.E. Theron, (2006). Rate of inbreeding and effective population size in four major South African dairy cattle breeds. South African Journal of Animal Science, 36, 50-57.

Matiwos Habte \& Selamawit Debele. (2014). Village chicken production performances assess-ment under scavenging management system in Amaro district, SNNPRS of Ethiopia. International journal of innovative research in technology and science, 2(8), 172-188.

Melkamu B. Y. \& A. Zewudu. (2013). Performance evaluation of local chicken at Enebsie Sar Midir Woreda, Eastern Gojjam, Ethiopia. Unique Research Journal of Agricultural Sciences, 1(2), 006-010.

Moreda E., S. Hareppal, A.Johansson, T. Sisaye \& Z. Sahile.
(2013). Characteristics of Indigenous Chicken Production System in South West and South Part of Ethiopia. British Journal of Poultry Sciences, 2(3), 25-32.

Moreki J. C., Dikeme R \& Poroga B. (2010). The role of village poultry in food security and HIV/AIDS mitigation in Chobe District of Botswana. Livestock Research for Rural Development. 22(55).

Nebiyu Y., B. Tamir \& K. Belihu. (2013). Characterization of village chicken production performance under scavenging system in Halaba district of southern Ethiopia. Ethiopia Veterinary Journal, 17(1), 6980.

Nigussie D., T. Dessie, Liesbeth H. van der Waaij \& Johan A.M. van Arendonk. (2010). Morphological features of indigenous chicken populations of Ethiopia. Animal Genetic Resources, 46,11-23.

Rusfidra M. G., Y. Gusrin, M. H. Abbas, H. Firda, A. K. Subekti \& Tertia D. Nova. (2015). Flock Composition, Effective Population Size and Inbreeding Rate of Kokok balenggek Chicken Breed under In-Situ Conservation. International Journal of Poultry Science, 14 (2), 117-119.

Solomon Z., B. Kassa, B. Agza \& F. Alemu. (2013). Village chicken production systems in Metekel zone, Northwest Ethiopia. Wudpecker Journal of Agricultural Research, 2(9), 256-262.

Tadele A., Melesse A. \& Taye M. (2018). Phenotypic and morphological characterizations of Indigenous chicken populations in Kaffa Zone, South Western Ethiopia. Animal Husbandry, Dairy and Veterinary Science, 2(1), 1-9.

Tadelle D. (2003). Phenotypic and genetic characterization of chicken ecotypes in Ethiopia. Ph.D Thesis. Humboldt University, Germany.Pp216.

Wondu M., M. Melaku \& B. Tamir. (2013). Characterization of Urban Poultry Production System in Northern Gondar, Amhara Regional State, Ethiopia. Agriculture and biology journal of North America. 4(3), 192.198.

Worku Z., Melesse A. \& T/Giorgis Y, (2012). Assessment of Village Chicken Production System and the Performance of Local Chicken Populations in West Amhara Region of Ethiopia. Journal of Animal Production, 2(4), 199-207. 